the liberation of lysocithin. R. J. Williams described the isolation and properties of pantothenic acid-a universal growth stimulant present in all cells. J. F. Toennies presented evidence that sensory stimulation may evoke a reflex which leads to the appearance of antidromic inpulses in dorsal spinal roots. A. v. Muralt demonstrated an apparatus which plunges nerve trunks into liquid air while impulses are actually passing, so that various evanescent effects of the impulses can be detected. F. Schütz demonstrated an apparatus for studying adsorption on foam, which may be useful in separating substances of physiological importance. J. S. Fruton described the results of the study of the action of various proteinases on simple peptides, which show that they may act specifically on the link between one particular pair of amino acids. A. C. Ivy demonstrated the masculinization of female rat embryos by the injection of male hormone into the mother during pregnancy, and also the reverse effect on male embryos. Another demonstration showed the same effect as the result of the injection of the embryos themselves by laparotomy. E. H. Venning and J. S. L. Browne described the results of a study of the physiology of progesterone by estimating its excretion product in the urine. R. D. Wright and H. W. Florey described interesting experiments on the secretion of the colon. L. A. Maynard, C. M. McCay and G. Sperling demonstrated experiments in which rats lived longer than normal rats and retained their youthful appearance, when they were fed on a diet which was deficient in calories, but otherwise complete.

The most popular discussions were on urinary excretion, the chemical transmission of nervous impulses, steroids, the adrenal cortex and the hypophysis. It was unfortunate that the last two of these discussions were held simultaneously.

The pharmacologists held a special meeting at which they discussed the scope and future of their science. Sir Henry Dale accused them of not taking an active interest in the important now remedies which are being introduced so rapidly, and of leaving the practical application of hormones, vitamins and chemotherapeutic agents to physiologists, biochemists and pathologists, who often have no medical training. Various speakers replied that pharmacological teaching does in fact keep up to date, and that pharmaco- logical research is more likely to be fruitful if pharmacologists are allowed to study what interests them, than if they are diverted to the study of the practical applications of the work of others. Pharmacology has been handicapped because it has been regarded as a handmaid of medicine. Its proper scope includes not only the study of the scientific basis of therapeutics, but also more general problems of how drugs act, methods of assay and standardization, the absorption and fate of drugs, factors determining the intensity of their action and their toxic effects not only on man, but also on other forms of life such as insects, weeds, worms, protozoa, and bacteria. The pharmacologist must know something of many sciences, but diversity of interests has been stimulating in the past and is likely to be so in the future.

On Thursday evening the members of the Congress were divided into groups with common interests, and entertained to dinner in various parts of Zurich. Interesting speeches of welcome and of gratitude were made and there were various other postprandial entertainments.

The final meeting was held on Friday afternoon. Prof. A. V. Hill presented the report of the permanent International Committee. Prof. L. A. Orbeli was elected to succeed Pavlov on this committee and there was some general discussion of procedure. Sir Henry Dale, on behalf of the Physiological Society, invited the Congress to meet in England in 1941 and this invitation was accepted. Prof. Houssay put forward an invitation to Buenos Aires in 1944, which was received with enthusiasm.

The Swiss committee is to be warmly congratulated on the arrangements for this Congress, which were simple and worked smoothly and without delay. Membership was limited to genuine physiologists approved as such by national committees, so that the temporary physiologists who have attended some recent congresses were excluded, but this arrangement is unfortunately open to abuse, since it makes it possible for genuine physiologists to be excluded for political reasons. About 1,100 members registered, and they were officially accompanied by 260 other persons. There were no Russians, but most other nations were well represented. A number of Spaniards, including Prof. Negrin, were able to come.

\title{
Twelfth International Horticultural Congress
}

$\mathrm{T}$ HE formal opening of the Twelfth International Horticultural Congress took place at 11 a.m. on August 12 in the Plenary Hall of the Congress Building (Kroll Opera House), Berlin, when the president, Herr R. Walther Darré, Reich Minister for Food and Agriculture and Reich Peasant Leader, gave a speech of warm welcome to all members, who represented about fifty nations. Addresses were also delivered by Herr Johannes Boettner, managing president; Prof. F. Angelini, first vice-president of the Congress; and Dr. J.J. L. van Rijn, vice-president of the International Institute for Agrieulture, Rome. The British delegation was headed by Dr. H. V. Taylor, of the Ministry of Agriculture, and included Sir Arthur Hill, Sir Frank Stockdale, Colonel F. R.
Durham, R. G. Hatton (East Malling), F. J. Chittenden and Dr. M. A. H. Tincker (Wisley).

In view of the numerous and varied horticultural problems to be discussed during the week, twenty sections were set up embracing all branches of horticulture, such as growing of fruits and vegetables, nurseries, nomenclature, park and garden planning, education, physiology, etc. As it was quite impossible to attend all the sectional meetings, the present account cannot claim to be complete, and mention can be made only of the few sections visited. In the Section of Education great interest was shown in the international exchange of young gardeners. M. Tubart outlined the existing position and made proposals for the further extension of the system. In 
the general discussion that followed, Sir Arthur Hill gave an account of the system of exchanges in operation at Kew. The first exchange was with Italy fifteen years ago and exchanges have since been made with Germany, France, Belgium, Holland, Denmark, Norway, Sweden, United States, Canada, South Africa, Australia and New Zealand.

In the Section of Nomenclature, under the chairmanship of Dozent A. Thorsrud, of Norway, it was obvious that there was a real desire to arrive at practical rules for the horticulturists, and there seemed to be very general agreement. Unlike the proceedings at the International Botanical Congresses, however, the voting on the nomenclature proposals is restricted to the members of the Permanent Committee in closed session. There was a very general feeling that some standard list of names of horticultural plants should be published, and Miss M. L. Green (Kew) gave an account of the work of the Special Committee on the Correct Names of Economic Plants (including Horticultural Plants), appointed at the International Botanical Congress, Amsterdam, 1935. This Committee will publish a list of the correct names of economic plants in accordance with the International Rules, which list will remain in force for ten years even if any of those names are in the meantime found to be not in accordance with the Rules. This will be an important factor in stabilising plant nomenclature.

On Monday, August 15, Colonel F. R. Durham, secretary of the Royal Horticultural Society, gave a special report on the object and purpose of exhibitions and trials of new varieties in regard to the advancement of horticultural breeding, and showed what a stimulating effect exhibitions and trials upon plant breeding have on modern horticulture.
In addition to the more serious work of the Congress, a very varied programme of excursions and entertainments was arranged and, as the large attendances showed, was much appreciated by the members. Visits were paid to various biological institutions such as the Reich Biological Institute for Agriculture and Forestry, the Experiment and Research Institute for Horticulture, and the Botanic Garden, Dahlem. Botanists attending the Congress were very glad to have the pleasure of renewing their associations with the Dahlem Herbarium and Gardens, where they were given a hearty welcome by the director, Prof. L. Diels, and his staff. Many motorcoach trips were arranged, and visits were paid to well-known nurseries such as that of Herr L. Späth at Retzin and of Herr K. Förster at Bornim.

Another feature of special interest was the exhibition entitled "500 years of German Gardening" organized by the Reich Ministry of Food and Agriculture. This was held in the Prussian State Library and illustrated the history of German garden flowers, fruits and vegetables, and the development of the style of German gardens from 1400 to 1900 . Interesting illustrations from ancient books, manuscripts and prints were on view, also drawings, engravings and oil paintings. The whole exhibit was extremely well planned and repaid careful study.

No account of the Congress would be complete without a word of admiration for the decorations at the Congress Buildings-there was a wealth of beautiful flowers to be seen everywhere. The names of the various halls were indications of the decorations within, such as the Tropical Hall, the Rose Hall, the Larkspur Hall, and the Fruit Hall. The thanks and congratulations of all members are due to the organizers of this very successful congress.

\section{Institution of Gas Engineers}

$\mathrm{T}$ HE seventy-fifth annual meeting of the Institution of Gas Engineers was held in London on May 31-June 3 when Sir David Milne Watson received the Birmingham Medal in recognition of his encouragement of research bearing on the manufacture and utilization of gas*. In his presidential address, Mr. H. C. Smith, of Tottenham, stated that the gas industry is under statutory obligation, subject to penalties, to supply gas of declared calorific value, prescribed purity and minimum pressure, whereas those who sell its raw material-coal-are encouraged by statute to raise the price of coal without any obligation as to its quality. He said that more than one million tons of useless material, which might have been removed from the coal at the collieries, had in 1937 been delivered to the gas works, to the detriment of both the carbonizer and the user of coke. $\mathrm{He}$ suggested that legislation concerning the coal industry should not stop at machinery for raising prices, but should impose obligations to supply coal of prescribed and regular quality.

Mr. E. V. Evans, discussing the processing of coal, said that the gas industry might be at the start of a new and greater era. The industry carbonizes coal primarily for the production of gas, and the by-products

* Institution of Gas Engineers. 75th Annual General Meeting, London, 31st May to 3rd June 1938. No. 177. Official Programme. Pp. 16. No. 178. Annual Reports and Accounts of the Council of the Institution of Gas Engineers. Pp. 44. No. 179. Presidential Address. By H. C. Smith. Pp. 24. No. 180. Considerations upon the Processing
of Coal. By E. V. Evans. Pp. 40. (Institution of Gas Engineers.) 28. -specially coke-are subsidized at the expense of the gas. For this reason, together with legal restrictions, the gas must be sold at prices which make it a luxury fuel. Before it can take its place as a staple fuel, gas must be freed from this burden, as is the case where it is a by-product of the manufacture of metallurgical coke. The ideal, it has long been recognized, would be to convert coal into a gaseous fuel of high calorific value. Experience where natural gas and cheap coke oven gas are available shows that the advantages of such a fuel lead to an enormous expansion in its use. During the last three years, the Joint Research Committee of the Institution of Gas Engineers and the University of Leeds has been examining the gasification of coal under pressure. It has been established that coal can be hydrogenated to yield gas and some liquid fuel without combustible residue under quite moderate pressures such as are current in steam boiler practice. The results leave no doubt that the complete gasification of the ashfree coal to form a high-grade gas is technically feasible and it remains to establish its economic future.

A paper by Dr. F. J. Eaton on the uses of coke revealed the rapid expansion in the consumption of gas coke since scientific study had shown what merits were to be found in this somewhat neglected smokeless fuel and how they could be turned to advantage.

H. J. H. 